Kumawula, Vol. 4, No.1, April 2021, Hal 177 - 182

DOI: https://doi.org/10.24198/kumawula.v4i1.32613

ISSN 2620-844X (online)

Tersedia online di http://jurnal.unpad.ac.id/kumawula/index

\title{
PENINGKATAN PENGETAHUAN MENGENAI PENTINGNYA MENJAGA KADAR HEMOGLOBIN DI DALAM DARAH PADA SISWI SMA NEGRI 1 GARUT
}

\author{
Umar Sumarna ${ }^{1}$, Furkon Nurhakim ${ }^{2}$, Udin Rosidin ${ }^{3}$ \\ ${ }^{1}$ Fakultas Keperawatan Universitas Padjadjaran \\ ${ }^{2}$ Fakultas Keperawatan Universitas Padjadjaran \\ ${ }^{3}$ Fakultas Keperawatan Universitas Padjadjaran
}

Korespondensi: umar.sumarna@unpad.ac.id: furkon.nurhakim@unpad.ac.id; udin.rosidin@unpad.ac.id;

\begin{abstract}
High school students consist of teenagers who are the nation's future successors, where their physical and intellectual development is developing, and are prepared to welcome a better future. Therefore, it is unfortunate if his health status is low, his body is weak, and less productive. This condition will occur if the levels of haemoglobin in the blood are low. In a preliminary study conducted at SMA Negeri 1 Garut it was found that in laboratory examinations, many of their students were proven to have low levels of haemoglobin, which is below $11 \mathrm{gr} \%$, especially famale students. The data was strengthened by the large number of famale students who were carried into the school health room after doing rather strenuous activities, such as sports, parade, scout activities and others. Efforts to overcome this have been made by the school authorities by collaborating with the local health center authorities by organizing school health activities. The real and specific program for female students at SMA Negeri 1 Garut is the Fe tablet distribution program. The problem at the school is the lack of success in distribution of Fe tablets in an effort to maintain haemoglobin levels in the blood. This happens caused of the lack of discipline of famale students in implementing the program, where many Fe tablets are discarded instead of being eaten, for various reasons. The method used is lectures, discussions and demonstrations. The results obtained showed that 71 famale students of SMA Negeri 1 Garut get a pre-test score of 4.55 until 90.91 and a post-test of 45.45 until 100.00, while an average pre-test score of 36,36, and an average post-test score of 68.18 with significancy score of 0.00. So, it can be concluded that the famale students of SMA Negeri 1 Garut are very enthusiastic in participating in health education related to the increase in haemoglobin levels in the blood.
\end{abstract}

Keywords : hemoglobin, female students, Fe tablet

\begin{abstract}
ABSTRAK
Siswa-siswi sekolah menengah terdiri dari anak-anak remaja calon penerus bangsa, di mana fisik dan intelektualnya sedang berkembang, serta dipersiapkan untuk menyongsong masa depan yang lebih baik. Oleh karena itu sangat disayangkan bila status kesehatannya rendah, tubuhnya lemah, dan kurang produktif. Kondisi tersebut akan terjadi bila kadar hemoglobin dalam darahnya rendah. Pada studi pendahuluan yang dilakukan di SMA Negeri 1 Garut ditemukan bahwa dalam pemeriksaan di laboratorium, banyak siswa-siswinya yang terbukti kadar hemoglobinnya rendah, yaitu di bawah $11 \mathrm{gr} \%$, terutama para siswinya. Data tersebut diperkuat dengan banyaknya para siswi yang dibopong ke ruang UKS setelah melakukan aktivitas yang agak berat, seperti olahraga, upacara, kegiatan pramuka dan lain lain. Upaya untuk mengatasi hal itu telah dilakukan oleh pihak sekolah dengan cara bekerja sama dengan pihak puskesmas setempat dengan menyelenggarakan kegiatan UKS. Adapun program yang nyata dan spesifik pada siswi di SMA Negeri 1 Garut adalah program pemberian tablet Fe. Masalah yang terdapat di sekolah tersebut adalah pada kurang berhasilnya program pemberian tablet Fe dalam upaya menjaga kadar hemoglobin dalam darah. Hal ini terjadi karena kurangnya disiplin para siswi dalam melaksanakan program tersebut, di mana tablet Fe tersebut banyak yang dibuang bukan dimakan dengan alasan yang bermacam-macam. Metode yang digunakan adalah ceramah, diskusi dan demonstrasi. Hasil yang didapatkan menunjukkan, bahwa responden siswi SMA Negeri 1 Garut sebanyak 71 orang memperoleh nilai pre-test 4,55 s.d 90,91 dan nilai post-
\end{abstract}


test 45,45 s.d 100,00, sementara nilai rerata pre-test 36,36 , dan nilai rerata post-test 68,16 dengan nilai signifikansi 0,00 . Maka dapat disimpulkan bahwa para siswi SMA Negeri 1 Garut sangat antusias dalam mengikuti pendidikan kesehatan yang berkaitan dengan peningkatan kadar hemoglobin dalam darah.

Kata Kunci: hemoglobin, siswi, tablet Fe

\section{PENDAHULUAN}

Darah adalah suatu komponen di dalam tubuh manusia yang sangat penting bagi tubuh manusia, fungsinya antara lain untuk mengantarkan zat-zat nutrisi dan oksigen untuk diedarkan ke seluruh jaringan tubuh manusia. Sementara bisa masuknya oksigen ke seluruh jaringan memerlukan substansi khusus sebagai media perantara. Adapun media perantara tersebut tidak lain adalah hemoglobin yang mampu mengikat oksigen sehingga menjadi senyawa yang disebut oksihemoglobin (Sartika, 2019). Sementara fungsi oksigen adalah sebagai bahan bakar untuk menguraikan zat-zat nutrisi dalam tubuh sehingga menjadi bahan yang bermanfaat bagi metabolisme tubuh.

Suatu kondisi yang dibutuhkan oleh tubuh agar hemoglobin bekerja secara efektif dalam tubuh manusia adalah kadarnya dalam darah cukup memadai, yaitu sekitar 12 s.d 14 gr \%. Namun, pada kenyataannya banyak kaum remaja yang memiliki kadar hemoglobin kurang dari $12 \%$, kondisi ini disebut anemia (Briawan, 2014).

Efek yang disebabkan oleh anemia yang terutama adalah pusing-pusing dan mudah lelah (Soebroto, 2015). Hal ini tentu saja kondisi yang tidak menguntungkan bagi remaja yang penuh dengan aktivitas, seperti aktivitas belajar, olah raga, bahkan bekerja, lebih-lebih lagi bagi remaja putri sebagai calon ibu. Banyak sekali bahaya yang ditimbulkan oleh ibu berhubungan dengan adanya perdarahan. Perdarahan pada penderita anemia berisiko tinggi terjadinya kematian (Briawan, 2014).

Seperti pada umumnya sekolah menengah yang ada di Indonesia, maka SMA Negri 1 Garut merupakan salah satu sekolah di Kabupaten Garut dengan jumlah siswa yang cukup tinggi yaitu 1.304 peserta didik. Dari jumlah tersebut lebih dari setengahnya merupakan remaja putri. Di SMA Negeri 1 Garut banyak sekali fasilitas untuk menunjang kegiatan belajar. Selain ruang kelas, terdapat juga perpustakaan, laboratorium biologi, kimia, fisika, dan komputer.

Dengan banyaknya fasilitas tersebut, tentu saja menunjukkan adanya banyak kegiatan di SMA Negeri 1 Garut. Kenyataannya, SMA Negri 1 Garut memiliki banyak kegiatan-kegiatan sekolah, seperti kegiatan ekstrakurikuler dan keorganisasian seperti Majelis Permusyawaratan Kelas (MPK), Organisasi Siswa Intra Sekolah (OSIS), Kelompok Ilmiah Remaja (KIR), School of Music Artistic Harmony and Simphony (SMASH), dan Olahraga Prestasi.

Dari banyaknya kegiatan tersebut, maka dibutuhkan stamina yang kuat dan segar dari para remaja siswa-siswi SMA Negeri 1 Garut. Maka tubuh mereka memerlukan zat nutrisi yang cukup (Setyawati \& Hartini, 2018). Zat nutrisi tersebut sangat dibutuhkan untuk pembentukan hemoglobin. Seperti yang telah disebutkan di atas bahwa hemoglobin sangat dibutuhkan oleh tubuh untuk mengikat oksigen.

Salah satu upaya sederhana yang biasa dilakukan dalam program kesehatan di Indonesia untuk mencegah atau menurunkan kasus anemia adalah pemberian tablet $\mathrm{Fe}$, dengan pertimbangan teoritis bahwa tablet $\mathrm{Fe}$ merupakan unsur dari luar tubuh sebagai substansi pembentuk hemoglobin (Soebroto, 2015).

Studi pendahuluan dilakukan penulis dengan mewawancarai 15 siswi SMA Negeri 1 Garut dari berbagai kelas. Hasilnya diketahui bahwa sebenarnya di SMA Negeri 1 Garut telah dilaksanakan program pemberian tablet $\mathrm{Fe}$ tersebut, namun program tersebut kurang berhasil, disebabkan sebagian besar siswi SMA Negeri 1 Garut tidak rutin memakan tablet Fe yang diberikan oleh guru BK (Bimbingan dan Konseling) karena berbagai alasan.

Beberapa siswi menyebutkan bahwa mereka menganggap memakan tablet $\mathrm{Fe}$ tersebut adalah hal yang sia-sia dan membuang 
waktu. Hal ini bisa terjadi berhubungan dengan rendahnya tingkat pengetahuan remaja tentang masa pubertas (Nuryani, 2015).

Ada pula yang menyebutkan bahwa orang tua mereka melarang memakan tablet $\mathrm{Fe}$ tersebut karena mereka memercayai beberapa mitos terkait tablet $\mathrm{Fe}$ tersebut, seperti bila memakan tablet $\mathrm{Fe}$ sama saja dengan makan darah haid yang dikeluarkan, darah haid akan bertambah banyak dan beberapa alasan lain. Pengaruh orang tua seperti ini sangat merugikan siswa-siswi. Menurut Sumarni (2020), orang tua memegang peranan penting dalam mengontrol dan mengawasi konsumsi makanan pada anak.

Mitos-mitos tersebut tentu saja sangat menyesatkan yang akhirnya merugikan para siswi yang sedang menginjak masa remaja putri. Menurut Ardayani \& Sitorus (2020), bahwa jika remaja tidak tepat dalam mencari informasi yang mereka butuhkan dapat berdampak buruk bagi diri dan kehidupannya. Sementara informasi dan pengetahuan yang baik akan memberikan pengaruh yang besar terhadap sikap yang positif diaplikasikan dalam kehidupan sehari hari (Fitriani, 2011).

Kenyataan tersebut di atas merupakan gambaran ketidakberhasilan program pemberian tablet $\mathrm{Fe}$ yang dikhawatirkan akan berdampak buruk pada status kesehatan para siswi SMA Negeri 1 Garut. Wujud dari ketidakberhasilan program tersebut telah terbukti dengan banyaknya siswi yang sedang mengalami haid dibawa ke ruang UKS (Usaha Kesehatan Sekolah) karena mengalami kram dan bahkan mengalami gejala anemia seperti pusing, mual, lemas, merasa lemah, tangan dan kaki terasa dingin, beberapa anggota PMR (Palang Merah Remaja) yang menolong para siswi tersebut mengatakan bahwa siswi juga terlihat pucat. Setelah diperiksa di laboratorium sekolah oleh petugas UKS, siswi yang mengalami gejala anemia tersebut kadar hemoglobinnya di bawah $11 \mathrm{gr} \%$.

Bila kondisi ini berlangsung terus menerus maka prestasi para siswi tersebut akan menurun dan aktivitas sekolah yang biasa dilakukan akan terganggu. Sementara bila korban lainnya banyak berjatuhan, maka akan terjadi penurunan prestasi sekolah secara keseluruhan. Padahal SMA Negeri 1 Garut telah dikenal memiliki prestasi yang paling unggul di Kabupaten Garut, bahkan sudah cukup disegani juga di Jawa Barat.

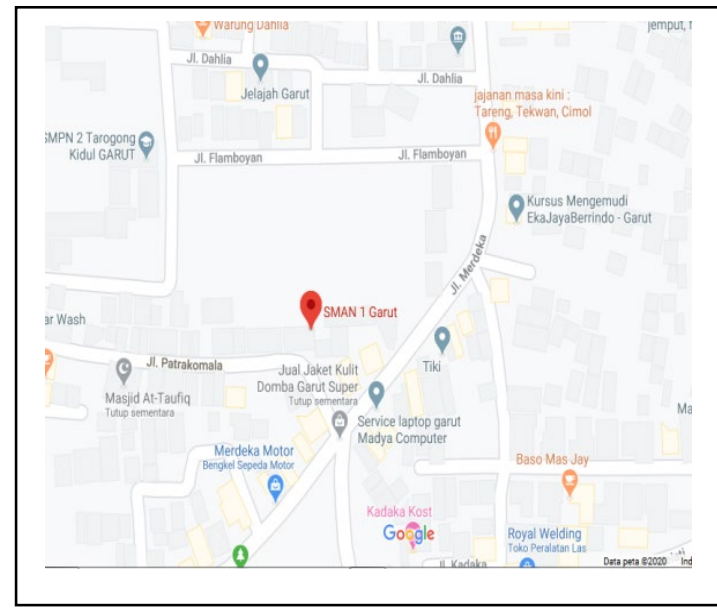

Gambar 1. Peta Lokasi Kegiatan

(Sumber: Google Maps)

\section{METODE}

Metode penyuluhan yang digunakan dalam PKM ini terdiri dari tiga metode (Nurdiyansyah \& Fahyuni, 2016) yaitu :

1. Metode ceramah. Metode ini dapat mempermudah peserta didik dalam hal ini yaitu Remaja Putri siswa SMAN 1 Garut sehingga mereka dapat menambah pengetahuan dan mungkin merasa lebih yakin kenapa mereka harus melakukan halhal seperti apa yang telah mahasiswa paparkan pada materi upaya peningkatan pengetahuan remaja putri di SMAN 1 Garut dalam menjaga kadar hemoglobin guna mencegah stunting.

2. Metode diskusi. Dengan metode ini, remaja putri juga dilatih untuk lebih memahami materi yang disampaikan sehingga mereka dapat membagikan atau menukar pengetahuan (sharing knowledge) yang mereka miliki kepada sesama peserta didik. Setelah sesi diskusi, mahasiswa sebagai pemberi materi dapat menanyakan sekaligus mengevaluasi seberapa paham siswa dan siswi terhadap materi yang di berikan. Menurut learning phyramid, dengan melakukan diskusi, peserta didik lebih mudah memahami materi yang disampaikan 
pada saat lecture. Di mana diskusi memiliki persentase $50 \%$ sementara lecture hanya 5\%. Hal ini sejalan hasil penelitian Elba \& Wijaya (2018), bahwa metoda diskusi lebih efektif daripada metode ceramah.

3. Metode demonstrasi. Metode ini dilakukan dengan cara memutarkan video, seperti video bagaimana cara menjaga kadar hemoglobin. Sehingga, setelah video diputarkan remaja putri dapat lebih mengingat apa yang telah disampaikan oleh mahasiswa karena dengan mendemonstrasikan/memperagakan itu akan menstimulasi semua indera. Metode ini dipandang lebih efektif dibanding metode ceramah dan diskusi (Elba \& Wijaya, 2018).

Sebelum ketiga metode tersebut di atas, tingkat kebutuhan belajar siswi dikaji dulu dengan melakukan pre-test terlebih dahulu, kemudian hasilnya direkap. Demikian juga setelah penyuluhan dilakukan post-test. Melalui pre-test dan post-test penulis berharap akan tergambar kebutuhan belajar siswi pada saat ini untuk diinformasikan pada gurunya di SMA Negeri 1 Garut, supaya dijadikan bahan dalam menyelenggarakan pembelajaran berikutnya.

\section{HASIL DAN PEMBAHASAN}

Setelah dilakukan pre-test dan post-test terhadap 71 siswi SMA Negeri 1 Garut. Model evaluasi seperti ini dilakukan supaya terukur secara kuantitatif (Riyono, 2020). Adapun hasilnya dapat dibandingkan seperti terlihat pada tabel dibawah ini :

\section{Tabel 1. Rata-rata Nilai Pre-test dan Post-test} Siswi $(\mathbf{N}=\mathbf{7 1})$

\begin{tabular}{|l|l|c|c|}
\hline No & \multicolumn{1}{|c|}{ Nilai } & $\begin{array}{c}\text { Pre- } \\
\text { test }\end{array}$ & $\begin{array}{c}\text { Post- } \\
\text { test }\end{array}$ \\
\hline 1 & Minimal & 4,55 & 45,45 \\
\hline 2 & Maksimal & 90,91 & 100,00 \\
\hline 3 & Rerata & 36,36 & 68,18 \\
\hline 4 & SD & 24,79 & 15,38 \\
\hline 5 & Sign & \multicolumn{2}{|c|}{0,00} \\
\hline
\end{tabular}

Tabel di atas menunjukkan adanya peningkatan, di mana nilai peroleh pre-test dari 4,55 s.d 90.91 menjadi 45,45 s.d 100,00 pada nilai post-test, sementara nilai rerata pre-test sebesar 36,36 menjadi 68,18 pada nilai rerata post-test. Secara keseluruhan perubahan cukup bermakna dengan nilai signifikansi 0,00 .

Melihat hasil pembelajaran ini tampak terjadi peningkatan pengetahuan siswi SMA Negeri 1 Garut. Hasil ini sesuai dengan hasil pembelajaran yang dilakukan oleh Sartika dkk (2019), di mana peningkatan pengetahuan tentang anemia pada remaja putri setelah dilakukan pendidikan kesehatan.

Berdasarkan hasil pre-test dan post-test tersebut, tergambarkan pula bahwa kebutuhan belajar siswi cukup variatif, yaitu sebagian perceived needs, sebagian unperceived needs, dan sebagian lagi misperceived needs (Dimyati,2017).

Dikatakan perceived needs, bila siswi tersebut mengetahui dampak dari perilaku tidak menjaga kadar hemoglobin di dalam tubuh dan pentingnya mengkonsumsi tablet $\mathrm{Fe}$ bagi wanita yang sedang menstruasi. Dikatakan unperceived needs, bila siswi tersebut belum mengetahui dampak dari perilaku tidak menjaga kadar hemoglobin di dalam tubuh dan pentingnya mengkonsumsi tablet Fe bagi wnita yang sedang menstruasi, dan dikatakan misperceived needs, bila siswi tersebut mengetahui dampak dari perilaku tidak menjaga kadar hemoglobin di dalam tubuh, antara lain berbahaya bagi kesehatan, baik jangka panjang maupun jangka pendek.

Berhubungan dengan ketiga kebutuhan belajar yang berbeda-beda pada masing-masing siswi, tentunya metode belajar yang lebih efektif dapat dilakukan dengan mengelompokkan siswi dengan kebutuhan belajar yang sesuai (Abin, 2017). Cara itu bisa saja dilakukan pada saat melaksanakan program co-kurikuler atau ekstrakurikuler disamping program kurikuler yang tetap dilaksanakan secara rutin untuk seluruh siswi sesuai jadwal yang telah ditetapkan.

Tanggung jawab tersebut bisa dipikul oleh wali kelas masing-masing siswa. Maka sebaiknya setiap wali kelas harus mengenal karakter dan kebutuhan belajar setiap siswi bimbingannya secara lebih detail. 


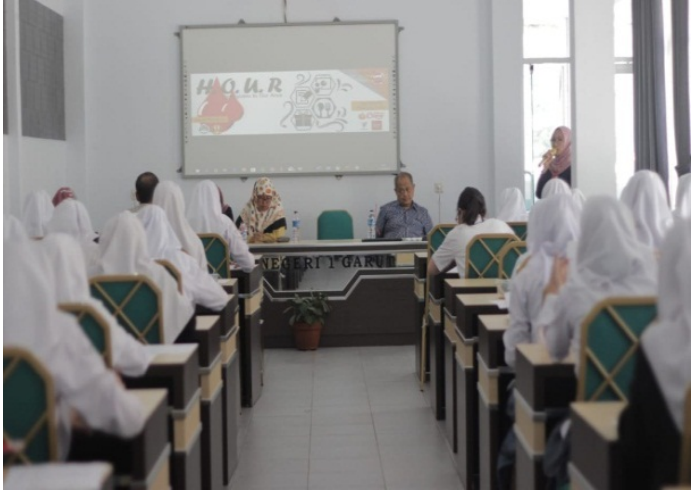

Gambar 2. Pembukaan pelaksanaan kegiatan penyuluhan (Sumber: Dokumentasi pribadi)

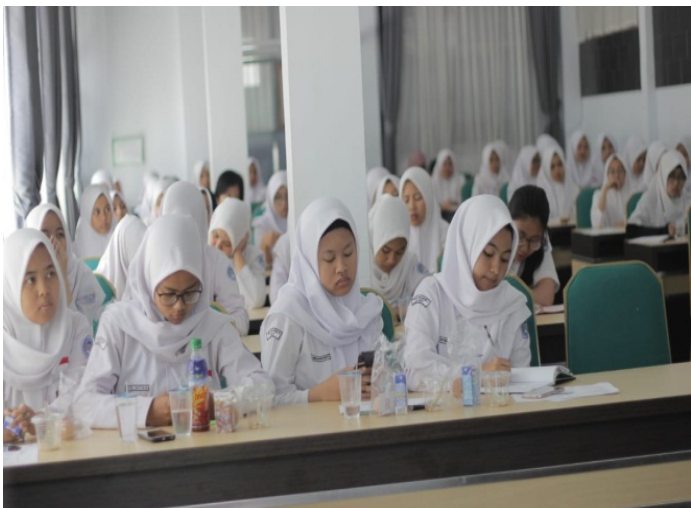

Gambar 3. Pelaksanaan post-test peserta (Sumber: Dokumentasi pribadi)

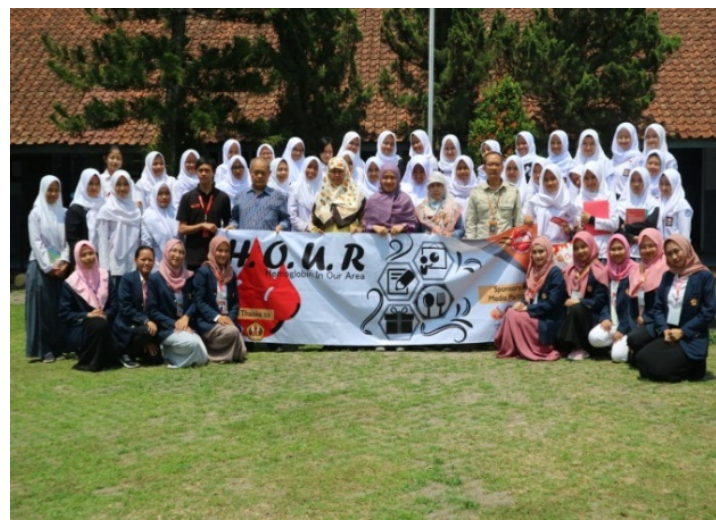

Gambar 4. Foto kebersamaan di akhir kegiatan penyuluhan

(Sumber: Dokumentasi pribadi)

\section{SIMPULAN}

Berdasarkan pengkajian kebutuhan belajar didapatkan bahwa kebutuhan belajar siswi SMAN 1 Garut, meliputi kebutuhan belajar perceived needs, unperceived needs, dan misperceived needs. Di mana sebagian siswi mengetahui akan pentingnya kadar hemoglobin $\mathrm{Hb})$ dalam tubuh, sebagian siswi ada yang tidak mengetahui akan pentingnya kadar hemoglobin $(\mathrm{Hb})$ dalam tubuh, dan sebagian siswi yang mengetahui pentingnya kadar hemoglobin $(\mathrm{Hb})$ tapi tidak peduli.

Setelah pendidikan kesehatan dilakukan, tampak adanya antusias dari sebagian besar siswi dalam mengikuti acara ini, terbukti dengan lancarnya interaksi dan tanya jawab antara siswi dengan pihak penyuluh.

Evaluasi kegiatan dilakukan dalam bentuk pre-test dan post-test tertulis. Hasil evaluasi menunjukkan rerata nilai pre-test sebesar 36,36 (min:4,55-maks:90,91) meningkat menjadi 68,18 (min:45,55maks:100 ).

Dengan demikian muncul harapan kami bahwa siswi SMA Negeri 1 Garut dapat menerapkan hasil PPM ini dalam kehidupan sehari-hari, khususnya dalam upaya menjaga kadar hemoglobin dalam tubuh masing-masing, sehingga tidak terjadi anemia.

\section{DAFTAR PUSTAKA}

Abin, Syamsuddin Makmun. 2017. Psikologi Kependidikan Perangkat Pengajaran Modul. Bandung: Remaja Rosdakarya.

Ardayani, Tri \& Sitorus, Neti. 2020. Peningkatan Pengetahuan Tentang Pubertas Pada Siswa Kelas 4.5.6 SD Negeri Sukawening Kecamatan Ciwidey Kabupaten Bandung. JPKMI Vol 1 no 4 Hal 253-261.

Briawan, Dodik. 2014. Anemia, Masalah Gizi pada Remaja Wanita. Jakarta: EGC

Dimyati, Ahmad dan Mudjiono. 2017. Belajar \& Pembelajaran. Jakarta: Rineka Cipta.

Elba, Fardila \& Wijaya, Merry.2018. Pengaruh Pembekalan Materi Kesehatan Reproduksi tentang Bahaya Pernikahan Dini untuk Remaja Putri. Dharmakarya Vol 8 no 1 Hal 1-5.

Fitriani. S. 2011. Promosi Kesehatan. Ed 1. Yogyakarta: Graha Ilmu

Nurdiyansyah., Fahyuni, Eni Fariyatul 2016. Inovasi Model Pembelajaran. Sidoarjo: Nizamia Learning Center. 
Nuryani, Lisa. 2015. Tingkat Pengetahuan Remaja Tentang Masa Pubertas. Jurnal Ilmu Kesehatan Aisyah (1): 48-55.

Riyono, Joko., Pujiastuti, Christina Eni. 2020. Evaluasi Pelatihan Pembuatan Forecasting untuk Perancangan Produk Berorientasi Pasar dengan Minitab kepada Karang Taruna di Bekasi. Kumawula: Jurnal pengabdian Masyrarakat. Vol. 3, No.2, Agustus 2020, Hal 348 - 357.

Sartika, Wiwi., Yosi Suryarinilsih., Herwati., Murniati M. 2019. Peningkatan Pengetahuan tentang Anemia pada Remaja Putri Sesudah diberikan pendidikan Kesehatan Gizi dengan Media Buklet di SMP Sabbihisma Padang. Ensikloperdia of Journal. Vol 2 no 1 Hal 123-127.

Setyawati, Vilda Ana Veria., Hartini, Eko. 2018. Dasar Ilmu gizi Kesehatan Masyarakat. Sleman: Deepublish.

Soebroto, Ikhsan., 2015. Cara mudah mengatasi problem Anemia. Yogyakarta: Bangkit

Sumarni, Nina., Rosidin, Udin., Sumarna, Umar. 2020. Penyuluhan Kesehatan tentang Jajanan Sehat di Sekolah di Sekolah Dasar Negeri Jati III Tarogong Kaler. Kumawula: Jurnal pengabdian Masyrarakat.Vol. 3, No.2, Agustus 2020, Hal $289-297$. 